Thorning, L., Bower, M., Hardwick, C. D. \& Hood, P. J. 1986: Greenland ice cap aeromagnetic survey 1985: magnetic measurements over the southern end of the Greenland ice cap. Rapp. Grønlands geol. Unders. 130, 86-90.
M. B.,

Flight Res. Sect.,

Bldg. $U-61$,

Nat. Research Council,

Montreal Road,

Ottawa, Ontario,

Canada, K1A OR6.
C. D. H.,

Flight Res. Lab., Nat. Research Council, Montreal Road,

Ottawa, Ontario, Canada, KIA OR6.
P. J. H. Regional Geophysics Subdiv., Resource Geophys. and Geochem. Div. Geological Survey of Canada, 601 Booth Street, Ottawa, Ontario, Canada, K1A OES.

\title{
Reconnaissance investigations in the Skjoldungen region, South-East Greenland
}

\author{
Troels F. D. Nielsen and Jan C. Escher
}

From 1 July to 25 August 1987 a GGU expedition made reconnaissance investigations between $62^{\circ} \mathrm{N}$ and $64^{\circ} 20^{\prime} \mathrm{N}$ in South-East Greenland. The programme was a continuation of the investigations in the Ammassalik/ Angmagssalik district in 1986 (Kalsbeek \& Nielsen, 1987) and the completion of the fieldwork describing areas in East Greenland between $62^{\circ} 30^{\prime} \mathrm{N}$ and $65^{\circ} 45^{\prime} \mathrm{N}$ for the planned map sheet (no. 14) in the 1:500 000 geological map series. The Skjoldungen district was known mainly from previous boat-supported work in the coastal areas as described by Bridgwater \& Gormsen, 1969; Andrews et al., 1971, 1973; Bridgwater et al., 1976; Escher \& Nielsen, 1982, 1983; Nielsen \& Escher 1985 and Escher et al., 1986.

\section{Organization}

The investigations were carried out as in 1986 in close co-operation with a team from the Geodetic Institute, Copenhagen, led by T. I. Hauge Andersson.

During an earlier airborne reconnaissance a camp site with a natural airstrip was located in the innermost part of Kagssortôq fjord (fig. 1). All equipment and personnel were transported to the base camp with a de Havilland Twin Otter (chartered by GI from Flugfélag Norourlands hf., Iceland) from Kulusuk airfield near Ammassalik. The field work was supported by an Aerospaciale Ecureil (AS 350 B1) helicopter (chartered by GGU from Uni-Fly, Denmark). Both aircraft were chartered through Greenlandair Charter $\mathrm{A} / \mathrm{S}$ and shared by GI and GGU.

The base camp was manned by P. Bay (materials, GGU), R. Fedder (cook, GGU), J. Wulff (radio communications, shared by GI and GGU) supported by $A$.
Petersen (GGU) and P. B. Andersen (GI), both students. The helicopter was operated by two crews: S. Forsstedt (pilot) and S. Nielsen (maintenance) during the first three and the last two weeks of the season and by U. Stoller (pilot) and C. Jørgensen (maintenance) between 23 July and 12 August. The preparation for the field work and co-ordination in the field were undertaken by T. F. D. Nielsen (GGU) in co-operation with T. I. Hauge Andersson (GI).

The group of geologists included five two-man teams (fig. 1): a northern mapping team: J. C. Escher (GGU) and M. J. Ryan (Portsmouth Polytechnic); a southern mapping team: B. Chadwick (University of Exeter) and B. J. Walton (Portsmouth Polytechnic); two interchangeable mapping teams: M. T. Rosing (Geologisk Museum, Copenhagen), V. N. Vasudev (Department of Mines and Geology, Bangalore, India), T. F. D. Nielsen (GGU) and A. Petersen (GGU); and an age dating team through the last four weeks of the season: F. Kalsbeek (GGU) and P. N. Taylor (Oxford University). Reporting on mineral occurrences was assigned to V. N. Vasudev and M. J. Ryan.

The northern and southern reconnaissance teams were mainly based in field camps and were supported by reconnaissance with a helicopter and rubber dinghy. The rest of the group worked mainly from the base camp, also supported by both a helicopter and rubber dinghies.

\section{Geology}

The area investigated during the field season broadly corresponds with the Archaean terrain of South-East Greenland (Andrews et al., 1973) which is bounded to 
Fig. 1. The region investigated during field work 1987. The areas investigated by different teams are indicated: I J. C. Escher \& M. J. Ryan; II V. N. Vasudev, M. T. Rosing \& T. F. D. Nielsen; III B. Chadwick \& B. J. Walton. Stars: Locality for sampling of material for radiometric age determination by F. Kalsbeek \& $\mathrm{P}$. N. Taylor. Filled circles: detailed investigations of supracrustal sequences.

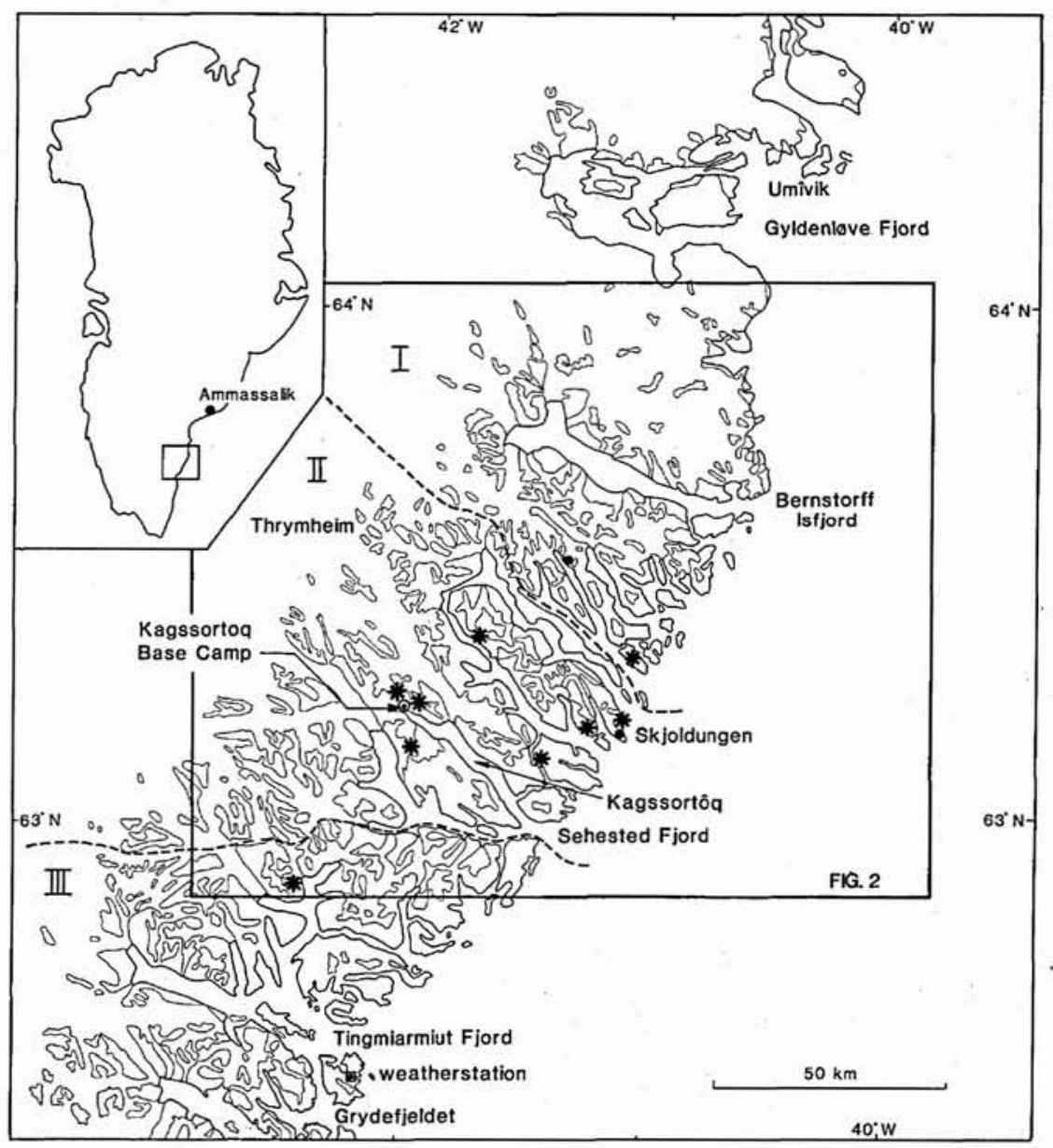

the north at $64^{\circ} 20^{\prime} \mathrm{N}$ by the Proterozoic 'Ammassalik mobile belt', previously called the Nagssugtoqidian of East Greenland (Bridgwater, 1976; Kalsbeek \& Nielsen, 1987; Escher et al., in press; Chadwick et al., in press) and to the south at $c .62^{\circ} 15^{\prime} \mathrm{N}$ by the acid volcanics and sediments of the Proterozoic Ketilidian mobile belt (Andrews et al., 1971, 1973).

Reconnaissance age dating from a variety of rocks (Escher et al., 1986) suggests that most of the gneisses were formed in the course of a major metamorphictectonic event 3000-2600 Ma ago. No evidence of early Archaean events has been observed.

A short description of the region, which has been divided into four areas each with its own geological characteristics, is given below. A detailed report of the summer's work will be given in a separate volume in GGU's report series.

\section{Gneisses and supracrustal rocks}

The region comprises gneissic and supracrustal rocks (fig. 2). The gneisses, which are the most common rock type, range from tonalitic to granitic and contain variable amounts of mafic inclusions. In the field they have been mapped as agmatitic gneisses and gneisses lacking inclusions, or with only a few. The bulk of the inclusions consist of amphibolites and ultramafic rocks and they have presumably been derived from supracrustal units. Together with the supracrustals they possibly represent the oldest rocks of the region. The supracrustals mainly comprise banded amphibolites with thin layers of ultramafic rocks, garnet-sillimanite paragneisses and quartzites. No igneous layering or pillow lava structures have been observed in the supracrustal sequences, but the impression is that most of the amphibolites are of volcanic origin.

Orthopyroxene has been identified in most of the gneisses and supracrustals throughout the region, even though most rocks have suffered retrogression to a variable extent.

The coastal area between Gyldenløve Fjord and Skjol- 


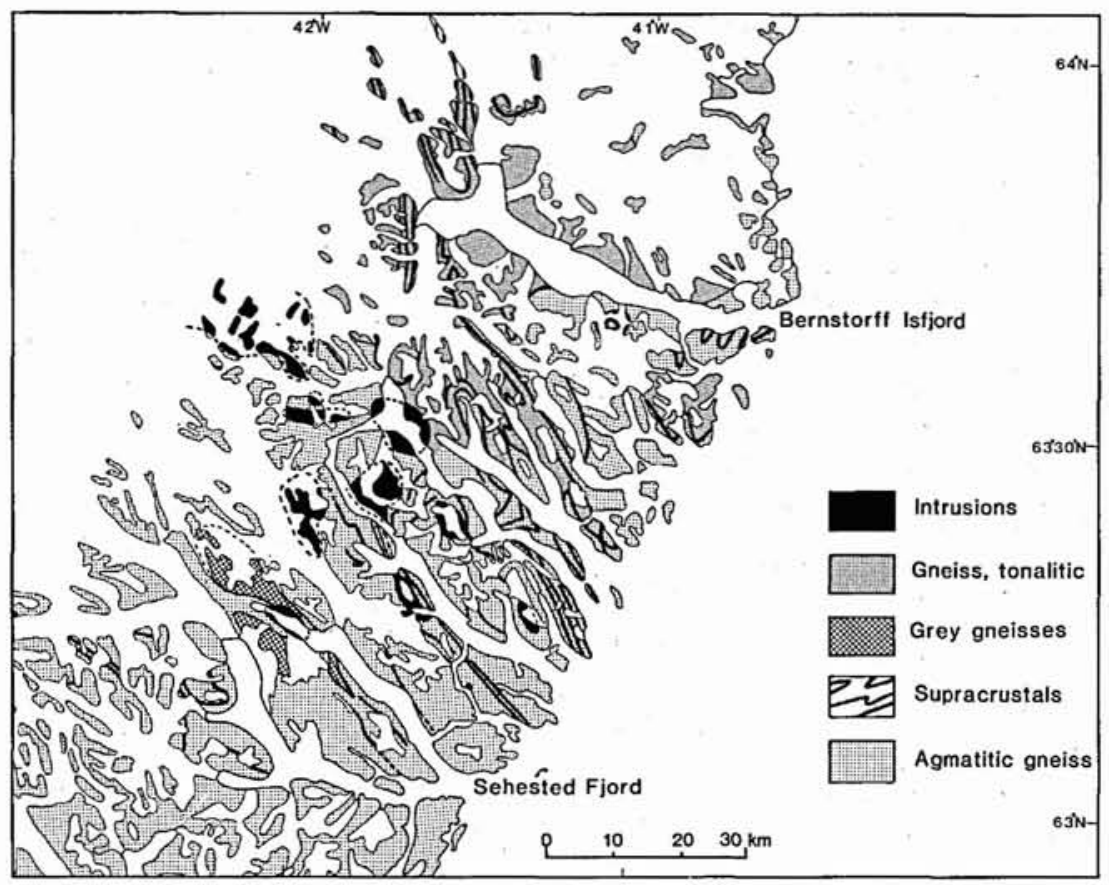

Fig. 2. Simplified geological map of the central part of the investigation area between Sehested Fjord and Bernstorff Isfjord showing the most important rock types.

dungen. Many supracrustal units can be traced along strike for $30 \mathrm{~km}$ or more, permitting large-scale interference fold patterns to be distinguished, which shows that the area has been affected by at least three major phases of deformation. The contact between gneisses and supracrustals is generally sharp and concordant; where local discordances occur, they are of tectonic origin. At a few localities a specific suite of lithologies occurs in the same order across strike: agmatitic gneiss, supracrustal amphibolite with thin ultramafics, metasediments and tonalitic to granitic gneiss with only few mafic inclusions. Folded and discordant trains of amphibolite inclusions show the occurrence of a few early dykes in the gneiss complex. The rocks are of amphibolite facies, but to the south near Skjoldungen orthopyroxene is frequently observed in the agmatitic gneisses and supracrustals.

The area along the margin of the Inland Ice between Gyldenløve Fjord and Skjoldungen. In contrast to the coastal area, the area along the margin of the Inland Ice has only a small proportion of agmatitic gneiss. The most common rock types are tonalitic-granodioritic gneisses and foliated granites, which all intrude banded amphibolites, ultramafic rocks and occasionally thin layers of metasediments. The supracrustals occur as elongated kilometre-sized rafts in the gneisses and granites. Regional folding has also here resulted in largescale interference patterns, and a few large, recumbent, isoclinal fold hinges are well exposed in steep cliffs. The rocks are of amphibolite facies, but to the south they become brownish weathered and orthopyroxene bearing.

The Skjoldungen - Thrymheim area. The area consists of a $c .35 \mathrm{~km}$ wide zone that runs NW-SE from the Inland Ice to the sea and includes brownish-weathered agmatitic gneisses, grey gneisses, thick units of supracrustal rocks and a suite of intrusive complexes. The agmatitic gneisses, which form the main rock unit of this area, are rich in mafic inclusions. In parts of the area they have been partially remelted, and the mobilisates appear to intrude both agmatitic gneisses and supracrustals. At two localities in the paragneisses a fine layering of possible primary origin is preserved. As in the northern area, the supracrustal amphibolites and metasediments are locally bounded by agmatitic gneisses on the one side and tonalitic to granitic gneisses (poor in inclusions) on the other side. Some of the supracrustal belts can be followed up to $20 \mathrm{~km}$ along strike, but in the southern part of the area they are rapidly disrupted and form trains of xenoliths in the agmatitic gneiss. Locally the matrix is very rich in quartz and has presumably been derived from remobilised quartz-rich metasedimentary paragneisses.

Up to $10 \mathrm{~km}$ wide homogeneous sheets of syenitic to granitic gneisses occur in the agmatitic gneisses. These 'grey gneisses' lack, or contain only a few, mafic in- 
clusions and may locally contain deformed, irregular, amphibolite dykes. Pegmatites related to these gneisses are often quartz-poor but are rich in large green amphibole.

The Skjoldungen area is characterised by a suite of intrusive bodies of gabbroic, dioritic, granitic and syenitic rock types. Similar intrusions have not been observed in the northern and southern parts of the region. They range from somewhat deformed to perfectly well preserved intrusions with well preserved primary magmatic textures. The largest gabbro and syenite complexes are found in the north-western part of Skjoldungen, whereas reddish-brown weathered granites dominate the nunatak area of Thrymheim. At present it is not clear whether the intrusions belong to several periods of plutonic activity or if they represent a suite of late- to post-tectonic intrusions.

The rocks in the coastal area from Skjoldungen and southwards to around Sehested Fjord are of granulite facies. In the rest of the area they are mainly amphibolite facies, but the presence of orthopyroxene indicates that at one time the agmatitic gneisses and the supracrustals attained granulite-facies conditions.

The region between Sehested Fjord and Tingmiarmiut weather station. This area is characterised by monotonous masses of agmatitic gneisses which represent about $95 \%$ of the rocks. The matrix is generally tonalitic and mafic inclusions are generally well rounded. An agmatised gabbro complex was also observed in the area. The only continuous supracrustal unit is found on Grydefjeldet west of Tingmiarmiut weather station. It is dominated by deformed amphibolites and minor garnetsillimanite-bearing paragneisses. The belt can be followed over about $10 \mathrm{~km}$ and forms a major fold. Orthopyroxene has been identified in most parts of the area, but apart from the area around Sehested Fjord which is of granulite facies the rocks are of amphibolite facies. Many of the gneisses are epidote and K-feldspar bearing, as a result of the late intense shearing described below.

\section{Alkaline complex}

By a stroke of luck the base camp was erected within the perimeter of a previously unknown alkaline complex. Only a small part of the complex is exposed on the shores of Kagssortôq. It is about $8 \mathrm{~km}^{2}$ in area and is composed of ultramafic, melteigitic, ijolitic and urtitic interlayered sheets cut by søvitic carbonatite and syenite dykes and pegmatites. The complex intrudes shear zones that affect all the gneiss types and most of the intrusions mentioned above. The age of the complex has not yet been determined.

\section{Dykes and sheets}

The earliest dykes are a few N-S orientated noritic dykes with characteristic interfingering contacts with the agmatitic gneisses. The dykes, which have not been identified north of Skjoldungen, appear fresh. They are followed by a dominant dyke generation of $20-80 \mathrm{~m}$ wide ENE-WSW orientated vertical dolerite dykes. South of Bernstorff Isfjord the dykes are unaltered magmatic rocks but northwards they become increasingly metamorphosed with amphibolitisation of their margins. In the Umîvik area at $64^{\circ} 20^{\prime} \mathrm{N}$ the dykes are severely epidotised and amphibolitised and still further to the north in the Ammassalik Mobile Belt the same dykes are strongly deformed (Bridgwater \& Gormsen, 1969).

Gently dipping green appinitic to carbonatitic sheets occur in the Tingmiarmiut region. They are of possible Ketilidian (middle-Proterozoic) age. In the same region a few NE-SW basaltic dykes of possible Gardar age ( $c$. $1200 \mathrm{Ma}$ ) have been observed.

The youngest of the dyke generations consists of 10 to $40 \mathrm{~m}$ wide $\mathrm{N}-\mathrm{S}$ trending dolerite dykes. They are often plagioclase phyric and very well preserved and are unaffected by shearing (see below). Similar dykes in the Umîvik area are regarded as Tertiary (Hall et al., in press).

\section{Shear and crush zones}

A characteristic of the Archaean belt in South-East Greenland is the large number of shear and brittle crush zones. The zones affect gneisses and supracrustals and some of the intrusions in the Skjoldungen area. Large areas have been intensely affected, which hinders observation work during helicopter reconnaissance. Most of the zones are retrogressed to greenschist facies and are heavily mineralised by $\mathrm{K}$-feldspar and epidote. A set of NE-SW trending zones cuts a NW-SE trending set. The alkaline complex is emplaced at a junction of major NW-SE and NE-SW shear zones, which it post-dates.

\section{Mineral occurrences}

Only a few mineral indications of possible economic interest have been noticed during the reconnaissance, and these are related to the supracrustal rocks. Some of the paragneisses are very rich in sillimanite (up to $50 \%$ ) and some of the quartzites contain only a little sillima- 
nite. Many of the paragneisses and the amphibolites contain sulphides, mostly pyrite and pyrrhotite. The alkaline complex contains small amounts of søvite carbonatite and has no anomalous radioactivity. Some of the søvites are rich in large apatite crystals and some of the pegmatitic feldspars show weak schillerization and contain massive sky blue cancrinite.

\section{References}

Andrews, J. R., Bridgwater, D., Gulson, B. \& Watterson, J. 1971: Reconnaissance mapping of South-East Greenland between $62^{\circ} 30^{\prime} \mathrm{N}$ and $60^{\circ} 30^{\prime} \mathrm{N}$. Rapp. Gronlands geol. Unders. 35, 32-38.

Andrews, J. R., Bridgwater, D., Gormsen, K., Gulson, B., Keto, L. \& Watterson, J. 1973: The Precambrian of SouthEast Greenland, In Park, R. G. \& Tarney, J. (edit.) The Precambrian of Scotland and related rocks of Greenland, 143-156. Birmingham U.P.

Bridgwater, D. 1976: Nagssugtoqidian mobile belt in East Greenland. In Escher, A. \& Watt, W. S. (edit.) Geology of Greenland, 97-103. Copenhagen: Geol. Surv. Greenland.

Bridgwater, D. \& Gormsen, K. 1969: Geological reconnaissance of the Precambrian rocks of South-East Greenland. Rapp. Grønlands geol. Unders. 19, 43-50.

Bridgwater, D., Keto, L., McGregor, V. R. \& Myers, J. S. 1976: The Archaean gneiss complex of Greenland. In Escher, A. \& Watt, W. S. (edit.) Geology of Greenland, 18-75. Copenhagen: Geol. Surv. Greenland.
Chadwick, B., Dawes, P. R., Escher, J. C., Friend, C. R. L., Hall, R. P., Kalsbeek, F., Nielsen, T. F. D., Nutman, A. P., Soper, N. J. \& Vasudev, V. N. in press: The Proterozoic mobile belt in the Ammassalik region, South-East Greenland (The Ammassalik mobile belt): an introduction and re-appraisal. Rapp. Grønlands geol. Unders.

Escher, J. C. \& Nielsen, T. F. D. 1982: Reconnaissance mapping of the rocks between Uivaq $\left(63^{\circ} 03^{\prime} \mathrm{N}\right)$ and Bernstorffs Isfjord $\left(63^{\circ} 38^{\prime} \mathrm{N}\right)$, South-East Greenland. Rapp. Grønlands geol. Unders. 110, 77-80.

Escher, J. C. \& Nielsen, T. F. D. 1983: Archaean gneisses and supracrustal rocks of the Tingmiarmiut region, South-East Greenland. Rapp. Gronlands geol. Unders. 115, 79-82.

Escher, J. C., Kalsbeek, F., Larsen, O., Nielsen, T. F. D. \& Taylor, P. N. 1986: Reconnaissance dating of Archaean rocks from South-East Greenland. Rapp. Grønlands geol. Unders. 130, 90-95.

Escher, J. C., Friend, C. R. L. \& Hall, R. P. in press: The southern boundary of the East Greenland Proterozoic mobile belt: geology of the area between Umîvik and Isortoq. Rapp. Gronlands geol. Unders.

Hall, R. P., Hughes, D. J. \& Joyner, L. in press: Basic dykes of the southern Ammassalik region, South-East Greenland. Rapp. Grønlands geol. Unders.

Kalsbeek, F. \& Nielsen, T. F. D. 1987: Regional geological investigations in the Ammassalik district, South-East Greenland. Rapp. Grønlands geol. Unders. 135, 59-66.

Nielsen, T. F. D. \& Escher, J. C. 1985: Preparations for the South-East Greenland mapping project 1986-1987. Rapp. Grønlands geol. Unders. 125, 84-87.

\title{
Sedimentological studies of the fluviatile-shallow marine Upper Triassic to Lower Jurassic succession in Jameson Land, East Greenland
}

\author{
Gregers Dam
}

A three-year research fellowship programme supported by British Petroleum Development, London, was initiated in the summer of 1987 . The main subject of the study is the Upper Triassic to Lower Jurassic succession in Jameson Land, East Greenland. This stratigraphic interval includes the Kap Stewart and the Neill Klinter Formations which have many features in common with some of the largest coeval hydrocarbon reservoir formations known in N.W. Europe (e.g. Statfjord field).

The core of the project is a lithofacies analysis but ichnology, palynology, source-rock analyses and porosity/permeability analyses will be included where relevant. If possible, corresponding intervals from the Nor- wegian continental shelf will be included in the project. The aim of the project is:

(1) to provide detailed and regional facies models for the two formations. Special stress will be laid on the physical stratigraphic relations in order to ascertain if regional unconformities are present and what order of magnitude they may represent.

(2) to establish a reservoir geological model which might help in the understanding of comparable reservoirs in the Norwegian-Greenland region. Particular attention will be paid to the geometry of individual sand bodies. 